\title{
Destination image, satisfaction and destination loyalty in cruise tourism: the case of Malaga (Spain)
}

\author{
Imagen del destino, satifacción del crucerista y lealtad al destino en el turismo de cruceros: el caso de Málaga \\ (España)
}

\author{
Elena Cruz Ruiz \\ University of Malaga, Faculty of Economics and Business, Department of Business Management, \\ Campus El Ejido, 29013 Malaga (Spain), ecruz@uma.es \\ Guillermo Bermúdez González \\ University of Malaga, Faculty of Economics and Business, Department of Business Management, \\ Campus El Ejido, 29013 Malaga (Spain), jbermudez@uma.es \\ Dolores Tous Zamora \\ University of Malaga, Faculty of Economics and Business, Department of Business Organization, \\ Campus El Ejido, 29013 Malaga (Spain), dtous@uma.es
}

\begin{abstract}
Over the past decades, cruise tourism is a sector that has experienced a tremendous growth around the globe. The relations that are established between the different agents that interact in this industry, passengers, crew and residents are crucial for visitor satisfaction and the success of the tourist destination. The study has analyzed the different types of cruise passengers who landed at the port of Malaga and their perception of the city through destination image, satisfaction and destination loyalty. A cluster analysis identified the existence of four different groups of passengers whose opinions can give a specific answer to the consolidation of Malaga as a quality tourist destination. From a practical point of view, recommendations about the adequate management of the destination's attractions for the cruise industry are discussed in the conclusions.
\end{abstract}

Keywords: Cluster analysis, destination image, cruise passengers satisfaction, destination loyalty, cruise tourism.

\section{Introduction}

A tourist destination comprises a set of resources and attractions where business organizations and institutions are working together in order to offer visitors an attractive image of the city and its experiences, understanding satisfaction that will be achieved by potential consumers (cruise tourists) through each and every one of the elements found in the environment (Ejarque, 2005).

In recent decades, the massive expansion of cruise tourism has become an interesting topic in cities such Malaga, whose tourist activity in the sector constitutes an important source of income.

Destination management depends on the ability of the agents to promote their own destination and also about how they perform their different roles and establish together a tourism development model, whose proper implementation will encourage progress over time (Valls, 2004).

We hypothesize that there are different segments of cruise passengers in relation to their perceptions about destination image, satisfaction and loyalty to the city of Malaga. We use a

\section{Resumen}

El turismo de cruceros es un sector que ha experimentado un enorme desarrollo en el mundo en las últimas décadas. Las relaciones que se producen entre los diferentes agentes que interactúan en esta industria, pasajeros, tripulación y residentes, son cruciales para la satisfacción de los visitantes y para el éxito del destino turístico. El estudio ha analizado las diferentes tipologías de cruceristas que arriban al puerto de Málaga y su percepción de la ciudad a través de la imagen del destino, la satisfacción y la lealtad al destino. Un análisis cluster demostró la existencia de cuatro grupos de pasajeros claramente diferenciados, cuyas opiniones pueden dar una respuesta específica, para avanzar en la consolidación de Málaga como destino turístico de calidad. Desde un punto de vista práctico, discutiremos en las conclusiones las recomendaciones para la adecuada gestión de las atracciones turísticas dedicadas al sector de los cruceros.

Palabras clave: Análisis cluster, Imagen del destino, Satisfacción del crucerista, Lealtad al destino, Turismo de cruceros.

cluster analysis in order to identify cruise passengers in different groups according to their comments about the city.

Malaga is nowadays living a special evolution, becoming day by day more cosmopolitan and a relevant destination in Europe. This city is not only the perfect destination for those in search of sun and sand at any time of year but also it is a cultural city concerns about the quality of the services and its image.

In this sense, the added value of this investigation is to offer a suitable basis about cruise passengers to the city of Malaga and to its institutions and companies with the aim of encouraging and promoting new touristic policies that develop a better tourist offer.

The intention has been to continue with the studies of other researchers who have analyzed the same variables in other parts of the world. In addition, the measuring instrument used (IDSL CRUISES-79) with all its variables can help us to analyze the image, satisfaction and loyalty of cruise passengers arriving at other ports around the world. 
The selection of destinations has strong ties with the attributes and attractions that passengers can find on the cruise ship, so the intention of buying a product is determined by the itinerary and services offered on board (Xie, Kerstetter \& Mattila, 2012).

A thorough review of the literature has been undertaken, which has served to recognize the factors that define the quality and success of a destination, developing a measuring instrument that allows us to analyze the different profiles of cruise passengers.

\section{Literature review}

The image of the destination is defined differently in academic literature and is a complex task that has evolved over time, (Lawson \& Baud-Bovy, 1977). Destination image was defined as an expression of knowledge, impressions, prejudices, imagination and emotion an individual has of a specific place. In terms of impressions, with reference to the fact that they may be true or false, real or imagined, we could quote Barich \& Kotler (1991). According to Tasci, Gartner \& Cavusgil (2007), destination image is an interactive system of thoughts and opinions and even the intentions with respect to a destiny.

As brought into evidence by numerous studies, destination image has been one of the key areas of tourism research for more than four decades, although, over time, theoretical elements were offered by other approaches (Stepchenkova \& Mills, 2010). Hunt was one of the pioneers in highlighting the importance of the destination image as a tool to increase the number of visitors to a place, noting that this variable is so important because it affects the choice of destination and individual tourist decisions. (Hunt, 1975)

From the point of view of tourism marketing, some researchers have attempted to clarify the nature of destination as a product, incorporating into their analysis the services that are demanded by tourists, describing them as multiple attributes of the destination that interact with travelers during their visit. For this reason, the tourist destination is considered as the market where, demand and supply of services, coexist together.

The tourist product should be seen in relation to the requirements and expectations of the customers, the tourists buy the total experience from when they leave home until they come back, therefore, it is defined as an array of services that constitute the entire tourism experience (Medlik \& Middleton, 1973).

The tourism product is a conjunction of natural, human and artificial elements and the tourist destination can be seen as the mixture of all the offers of services received by tourists, forming an entire tourism experience of the visited destination (Murphy, Pritchard \& Smith, 2000).

In relation to the aforementioned, there are researchers who have used different attributes to measure the image of a tourist destination, (Echtner \& Ritchie, 2003; Sonmez \& Sriakaya, 2002). Other experts have categorized the attributes that describe the variable into nine dimensions; natural resources, tourist leisure and recreation, natural environment, general infrastructure, culture, history and art, social environment, tourism infrastructure; and political and economic factors. (Beerli \& Martin, 2004).

In recent research, the authors Chi \& Qu are relevant because their studies are of great interest to our analysis; we are particularly interested in the analysis of the existing structural relations between the destination image, the satisfaction of cruise passengers and loyalty. It shows the impact of the destination image on the satisfaction experienced by the tourist. Regarding the variable, destination image, Chi \& Qu, analyze it contemplating nine aspects; travel environment, natural attractions, entertainment and events, historical attractions, infrastructure, accessibility, relaxation, outdoor activities and price and value (Chi \& Qu, 2008).

Many researchers agree that the image is generally formed by two key forces: stimulus or external factors and internal personal factors (Baloglu \& McCleary, 1999). The formers refer to the quantity and diverse nature of the sources of information, to which individuals are exposed, including destination information acquired as a result of having visited.

Among the latter the motivation, personality and lifestyle, sociodemographic characteristics and geographical and cultural origin of tourists are included (Beerli \& Martin, 2004). Age, education level, country of origin, marital status, income, among others, are aspects considered to constitute a profile. A variety of authors have taken them into account in their valuations. (Tasci, Gartner \& Cavusgil, 2007; Ferreira Lopes, 2011).

Based on these approaches and on the variable 'destination image', this research aims to analyze the tourists' appreciation of the city of Malaga. To do this, the study proposes contrasting the following hypothesis:

- $\mathrm{H}_{1}$ : In the Malaga context, regarding the perception of the destination image, there are different categories of cruise passengers.

In addition, in recent years, academic literature has focused much attention on satisfaction because it is understood as an antecedent of customer loyalty and, since the beginning of marketing; it has also been considered the determining factor of success in markets.

Tourist satisfaction is considered one of the main variables to ensure company competitiveness in the tourism industry, as it affects the choice of destination and consumption of goods and services (Kozak \& Rimmington, 2000). Several authors have defined this concept as the result derived from the comparison made by the consumer, between their expectations and perceived performance (Oliver, 1997). Others define satisfaction as personal feelings of pleasure or disappointment, resulting from comparing how the product is perceived in relation to their expectations (Giese \& Cote, 2000).

Kim \& Richardson, (2003) consider that customer satisfaction is an after-purchase attitude, formed by a mental comparison of 
product quality and service that a client expects to receive in an exchange.

Theories and approaches to the study of satisfaction are multiple because it is a complex concept that depends on several variables, in which many aspects of the consumer, such as cultural, economic, motivational, previous experiences and those relating to the product or service, their features, attributes, quality and costs are involved. So, it is considered that the level of satisfaction depends on two key factors: the human factor and the valuation of the ease and accessibility of services. The first is the one that exerted the greatest influence on satisfaction (Devesa \& Palacios, 2005).

The visitor satisfaction may generate positive consequences for companies in the tourism sector and for agencies in charge of promoting and tourism policies because they create a positive image of the city when they share their experiences with their environment.

A large number of researchers have devoted their studies to examine how the expectations were satisfied through attributes such as accommodation, dining, attractions, accessibility, commerce, services and leisure and the environment (Chi \& Qu, 2008).

In relation to the circumstances that may be taken into account to measure satisfaction, we could cite numerous authors who have recently done extensive research on certain attributes as a method to approach this topic. Relaxation, safety and infrastructure, cultural attractions and shops, tourist attractions, environment, variety and accessibility (Prayag, 2008).

Destination image, attitude, motivation, natural landscape, service and recreational facilities were attributes which affect tourist satisfaction (Lee, 2009).

Attributes like travel environment, price or value, accessibility and natural attractions as elements which influence tourist satisfaction (Alqurneh, Md Isa, \& Rahim, 2010). Accessibility, attractions and basic services in so far as they affect tourist satisfaction (Eusebio \& Vieira, 2011). Destination image, personal involvement, place attachment and overall satisfaction influence satisfaction of tourists (Prayag \& Ryan, 2012). Tourist attractions, basic facilities, cultural attractions, touristy substructures and accessibility, natural environment, variety and affordability influence tourist satisfaction (Coban, 2012).

In relation to the variable of satisfaction of cruise passengers, the following hypothesis has been considered:

- $\mathrm{H}_{2}$ : There are different categories of cruise passengers regarding the variable of satisfaction in their perception of the city of Malaga.

In the review of the recent literature it is well known that it is of little use to have a satisfied tourist with the services offered or with the attributes of a destination, if the tourists do not have the intention of demanding again these products or services or revisiting the destination or recommending it to others.

Market success will be influenced by the analysis of destination loyalty and its interaction with tourist satisfaction and destination image. Satisfaction with travel experiences contribute to destination loyalty. In addition, this loyalty is reflected in consumer intentions to revisit and in the willingness to recommend the destination.

The pursuit of loyalty as long as it stimulates future benefits, which the tourist activity reports, as the effect of the repetition of the visit and recommendations of satisfied tourists, is a line which can be perceived in consolidated or mature destinations (Fyall, Callod \& Edward, 2003; Shirazy \& Som, 2011).

In the field of tourism, we can realize that, in recent years, researchers have also incorporated the concept of consumer loyalty in relation to tourism products, and destination can be considered as such, tourists can return and/or recommend them to their closer environment (Chi \& Qu, 2008; Prayag \& Ryan, 2012).

Thus, positive experiences of tourists, word of mouth and recommendations from previous visits are the main sources of creating destination loyalty. In fact, the expert authors on the subject affirm that recommendations are one of the most sought types of information by people interested in traveling (Yoon \& Uysal, 2005).

Regarding the loyalty destination variable, the following hypothesis has been raised:

- $\mathrm{H}_{3}$ : There are different categories of cruise passengers with respect to destination loyalty in Malaga.

In this respect, loyalty to a particular destination has generally been seen as positive in the literature of marketing and tourism because it implies that we have satisfied tourists and that marketing campaigns works properly. The disclosure of the excellences of a destination affects promotion costs and at the same time when the tourist profile is known, marketing costs will be lower.

We could highlight other studies according to the relationship between these variables. In one of the recent research it has been analyzed the influence of cruise passengers' image of a Mediterranean port of call on visit satisfaction and future behavioral intentions, and the moderating role of culture in causal relationships among these constructs. (Sanz \& CarvajalTrujillo, 2014).

The results showed that image has a direct influence on satisfaction and satisfaction has a direct effect on future behavioral intention.

Also, the mentioned authors (Carvajal-Trujillo \& Sanz, 2015), have analyzes the process of image formation and the influence that image and cruise passenger satisfaction has on future behavioral intentions. This study showed that gender, age, 
education, and experience have a moderating influence on the image of ports of call, on cruise passengers' satisfaction, and on future behavioral intentions derived from cruise passengers' satisfaction.

\section{Methodology}

The study used a stratified probability sampling technique, whose main objective is to understand the behavior of tourists who arrive via cruise ship at the port of Malaga and their perception of the city. A questionnaire was prepared with a number of variables that are intended to describe and publish the profile of cruise passengers, determining the overall satisfaction that they show and also the perception of the destination image and consequently if they will repeat the visit to the city in the future.

The structured or multi-attribute approach technique for the construction of the questionnaire was used. It consists of the grouping of attributes set in advance, collecting the perception that cruise passengers have for each attribute through a Likert scale; psychometric scale commonly used in questionnaires, most widely used in research surveys (Echtner \& Ritchie, 2003).
The questionnaire is named IDSL CRUISES-79, taking in to consideration the first letters of the concepts studied in English, destination image, satisfaction of cruise passengers and destination loyalty, annexed to the basic appellation of our research "cruises" and the number 79, which includes a combination of issues that we raised. It is divided into 2 parts: the variables of the theoretical model and the provision of services and aspects of the cruise passenger profile.

The first block of the questionnaire IDSL CRUISES-79 consists of the three concepts under study, the destination image, the satisfaction of cruise passengers and destination loyalty, following previous analysis by other researchers and adapting the variables to the circumstances of the analyzed context. Each concept has been studied subdivided into several factors and, in turn, each factor is represented by several variables or items. (Chi \& Qu, 2009; Jamaludin, Johari, Aziz, Kayat, \& Yusof, 2012; Prayag \& Ryan, 2012; Zeithaml, Berry \& Parasuraman, 1996; Cater \& Zabkar, 2009; Chi, Xiaoxia, \& Honggang, 2013). The development of the questionnaire was based on an exhaustive review of the literature, as shown in Table 1.

Table 1 - Factors and variables IDSL CRUISES-79

\begin{tabular}{|c|c|c|c|c|c|c|c|c|}
\hline \multirow[b]{2}{*}{ FACTORS AND VARIABLES } & \multicolumn{8}{|c|}{ AUTHORS } \\
\hline & $\begin{array}{c}\text { Beerli, A. \& } \\
\text { Martin, J.D. } \\
(2004)\end{array}$ & $\begin{array}{l}\text { Geng-Quin } \\
\text { Chi, C. \& Qu, } \\
\text { H.(2008) }\end{array}$ & $\begin{array}{l}\text { Alqurneh, M. } \\
\text { et Al. (2010) }\end{array}$ & $\begin{array}{c}\text { Eusebio,C \& } \\
\text { Vieira, A.L. } \\
(2011)\end{array}$ & $\begin{array}{c}\text { Prayag, G. \& } \\
\text { Ryan, C } \\
(2012)\end{array}$ & $\begin{array}{l}\text { Hernández } \\
\text { Lobato, L. } \\
\text { (2012) }\end{array}$ & $\begin{array}{c}\text { Coban, S. } \\
(2012)\end{array}$ & $\begin{array}{c}\text { Rajesh, R } \\
\text { (2013) }\end{array}$ \\
\hline DESTINATION IMAGE ITEMS & & $\mathrm{x}$ & $\mathrm{x}$ & & $\mathrm{x}$ & & $\mathrm{x}$ & $\mathrm{x}$ \\
\hline \begin{tabular}{|l} 
TRAVEL ENVIRONMENT \\
\end{tabular} & & & & & & & & $\overline{\mathrm{x}}$ \\
\hline Pleasant weather & $\mathrm{x}$ & $\mathrm{x}$ & & & $\mathrm{x}$ & $\mathrm{x}$ & $\mathrm{x}$ & \\
\hline Clean and tidy environment & $\mathrm{x}$ & $\mathrm{x}$ & $\mathrm{x}$ & & $\mathrm{x}$ & $\mathrm{x}$ & & \\
\hline Friendly and helpful local people & $\mathrm{x}$ & $\mathrm{x}$ & & & $\mathrm{x}$ & $\mathrm{x}$ & $\mathrm{x}$ & \\
\hline Safe and secure envioronment & & $\mathrm{x}$ & $\mathrm{x}$ & & $\mathrm{x}$ & $\mathrm{x}$ & $\mathrm{x}$ & \\
\hline Pinturesque views & & & $\mathrm{x}$ & & & $\mathrm{x}$ & & \\
\hline \multicolumn{9}{|l|}{ ENTERTAINMENT AND EVENTS } \\
\hline Wide arrays of shows/exhibitions & & $\mathrm{x}$ & & & & $\mathrm{x}$ & & \\
\hline Wide variety of entertainment & & $\mathrm{x}$ & & & $\mathrm{x}$ & $\mathrm{x}$ & & \\
\hline Tempting cultural events & & $\mathrm{x}$ & & & & $\mathrm{x}$ & & \\
\hline INFRASTRUCTURES & & & & & & & & $\mathrm{x}$ \\
\hline Wide selection of restaurants/cuisine & $\mathrm{x}$ & $\mathrm{x}$ & & & $\mathrm{x}$ & & & \\
\hline Wide variety of shopping options & $\mathrm{x}$ & $\mathrm{x}$ & & & $\mathrm{x}$ & & & \\
\hline Wide choice of accommodation & $\mathrm{x}$ & $\mathrm{x}$ & & & $\mathrm{x}$ & & & \\
\hline PRICE AND VALUE & & & & & & & & $\mathrm{x}$ \\
\hline Reasonable price for food and accommodation & & $\mathrm{x}$ & $\mathrm{x}$ & $\mathrm{x}$ & & $\mathrm{x}$ & $\mathrm{x}$ & \\
\hline Good value for money & & $\mathrm{x}$ & $\mathrm{x}$ & & $\mathrm{x}$ & $\mathrm{x}$ & $\mathrm{x}$ & \\
\hline Reasonable price for attractions and activities & & $\mathrm{x}$ & $\mathrm{x}$ & & & & $\mathrm{x}$ & \\
\hline Good bargain shopping & & $\mathrm{x}$ & $\mathrm{x}$ & & & & & \\
\hline ACCESSIBILITY & & & & & $\mathrm{x}$ & & $\mathrm{x}$ & $\mathrm{x}$ \\
\hline Appropriate signposting & & & & $\mathrm{x}$ & & & & \\
\hline Easy access to city centre & $\mathrm{x}$ & $\mathrm{x}$ & $\mathrm{x}$ & & & $\mathrm{x}$ & & \\
\hline \multicolumn{9}{|l|}{ Disabled access } \\
\hline Tourism information points & $\mathrm{x}$ & & & & & $\mathrm{x}$ & $\mathrm{x}$ & \\
\hline SATISFACTION ITEMS & & $\bar{x}$ & $\bar{x}$ & & $\bar{x}$ & & $\bar{x}$ & $\bar{x}$ \\
\hline SHOPPING & & & & & & & & $\overline{\mathrm{x}}$ \\
\hline Variety of shops & & $\mathrm{x}$ & & & $\mathrm{x}$ & $\mathrm{x}$ & $\mathrm{x}$ & \\
\hline Friendliness of employess & & $\mathrm{x}$ & & & & & & \\
\hline Quality of goods & & $\mathrm{x}$ & & & & & & \\
\hline \multicolumn{9}{|l|}{ Flexible and ample timetable } \\
\hline CATERING & & & & & & & & $\mathrm{x}$ \\
\hline Quality of food & $\mathrm{x}$ & $\mathrm{x}$ & & $\mathrm{x}$ & & $\mathrm{x}$ & $\mathrm{x}$ & \\
\hline Variety of cuisine & $\mathrm{x}$ & $\mathrm{x}$ & & & $\mathrm{x}$ & $\mathrm{x}$ & $\mathrm{x}$ & \\
\hline \multicolumn{9}{|l|}{ Flexible and ample timetable } \\
\hline \multirow{2}{*}{\multicolumn{9}{|c|}{ Image/Appearance }} \\
\hline & & & & & & & & \\
\hline CULTURAL AND HISTORIC ATTRACTIONS & $\mathrm{x}$ & & & $\mathrm{x}$ & $\mathrm{x}$ & $\mathrm{x}$ & & $\mathrm{x}$ \\
\hline Variety of historic/cultural sites & $\mathrm{x}$ & $\mathrm{x}$ & & $\mathrm{x}$ & $\mathrm{x}$ & $\mathrm{x}$ & $\mathrm{x}$ & \\
\hline Variety of natural attractions (Green Spaces) & $\mathrm{x}$ & $\mathrm{x}$ & $\mathrm{x}$ & $\mathrm{x}$ & $\mathrm{x}$ & $\mathrm{x}$ & $\mathrm{x}$ & \\
\hline Reasonable price for sightseeing & & $\mathrm{x}$ & & & & & & \\
\hline ACTIVITIES AND EVENTS & & & & & & $\mathrm{x}$ & & $\mathrm{x}$ \\
\hline \multirow{2}{*}{\multicolumn{9}{|c|}{ Quality of events/shows }} \\
\hline & & & & & & & & \\
\hline Reasonable price for activities and events & $\mathrm{x}$ & $\mathrm{x}$ & & & & & & \\
\hline \multirow{2}{*}{\multicolumn{9}{|c|}{$\begin{array}{l}\text { ENVIRONMENT } \\
\text { EVIIIS }\end{array}$}} \\
\hline & & & & & & & & \\
\hline Clean and tidy environment & & $\mathrm{x}$ & & & & & & \\
\hline Friendly and helpful local people & & $\mathrm{x}$ & & & & & & \\
\hline Safe and secure envioronment & & $\mathrm{x}$ & & & $\mathrm{x}$ & & & \\
\hline \multicolumn{9}{|l|}{ Pinturesque views } \\
\hline DESTINATION LOYALTY ITEMS & & 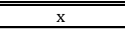 & 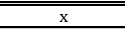 & & $\overline{\mathrm{x}}$ & & 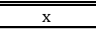 & $\overline{\mathrm{x}}$ \\
\hline Intention to revisit & & $\overline{\mathrm{x}}$ & & & $\overline{\mathrm{x}}$ & & & $\overline{\mathrm{x}}$ \\
\hline Intention to recommend & & $\mathrm{x}$ & & & $\mathrm{x}$ & & & \\
\hline Overall satisfaction & & & & & $\mathrm{x}$ & & & \\
\hline
\end{tabular}




\subsection{Measuring instruments}

\section{(1) Destination image:}

Based on the most important tourist literature, significant factors were selected to evaluate the destination image: Environment ( 5 variables), entertainment and recreation ( 3 variables), Infrastructure (3 variables), price and value (4 variables) and accessibility (4 variables).

IDSL CRUISES-79 includes a total of 19 variables and the variable "Disabled Access" has been included. A Likert scale of 7 values has been used, specifying the level of agreement or disagreement with the statement (variables).

It has followed the following priority: 1= Strongly Disagree, $2=$ Disagree, 3= Slightly Disagree, 4= Undecided, 5= Slightly Agree, 6= Agree and 7= Strongly Agree.

\section{(2) Satisfaction of cruise passenger:}

Regarding satisfaction of cruise passengers five factors have been selected: Shopping (4 variables), Catering (5 variables), Historical and cultural attractions (3 variables), and Leisure activities (4 variables) and Environment (4 variables). Three variables are given to the proposed model "Flexible and ample timetable" for Shopping and Catering and the "Image and Appearance" of this latter factor.

A 7-point Likert scale has been used, demonstrating the level of satisfaction or dissatisfaction with the statement (variable or items), which has followed the following priority: 1= Fully dissatisfied, 2= Dissatisfied, $3=$ Slightly dissatisfied, $4=$ Neutral or indifference, 5= Slightly satisfied, 6= Satisfied and 7= Fully satisfied.

\section{(3) Destination loyalty:}

In this study, destination loyalty contemplated for its analysis 3 factors, repetition of destination, recommendation of the destination and overall satisfaction of the visit, with a 7-point Likert scale being 1= Fully dissatisfied, 2= Dissatisfied, $3=$ Slightly dissatisfied, $4=$ Neutral or indifference, $5=$ Slightly satisfied, $6=$ Satisfied and 7= Fully satisfied.

Finally, the questionnaire consists of socio-demographic characterization of survey respondents who contribute to the classification of the sample: nationality, age ranges, gender and traveler profile.

\subsection{Reliability of the scale}

An analysis of the reliability of the scales was carried out through Cronbach Alpha, which allows estimating the reliability of a measuring instrument, through a set of items, which are expected to measure the same construct or theoretical dimension (Nunnally \& Bernstein, 1994). The measure of reliability by this indicator assumes that the items (Likert scale measured) measure the same construct and are highly correlated. The closer the value of the Alfa is within 1, higher the internal consistency of the items analyzed.

In our study, the reliability of the scale is reflected in Table 2:
Table 2 - Reliability Statistical IDSL CRUISES-79 scale

\begin{tabular}{|ccc|}
\hline ITEMS & $\begin{array}{c}\text { CRONBACH } \\
\text { ALPHA }\end{array}$ & VARIABLES No \\
\hline Destination Image & 0,974 & 19 \\
Cruise Passenger Satisfaction & 0,979 & 20 \\
Destination Loyalty & 0,914 & 3 \\
\hline
\end{tabular}

Source: Authors.

Reliability levels obtained with Cronbach Alpha method into each of the dimensions, ranged from 0.914 and 0.979 . These results reflect a high level of internal consistency in the questionnaire IDSL CRUISES-79, scales the destination image, cruise passenger's satisfaction and destination loyalty were reliable, as Cronbach Alphas were greater than 0.9. An alpha of 0.7 or above is acceptable considered as a good indication of reliability (Nunnally \& Bernstein, 1994).

\subsection{Sampling}

We chose cruise ship of different nationalities, companies and sizes. We selected cruise passengers after visiting Malaga at the entrance of Malaga Port.

After collecting and debugging the information, aimed at cruise passengers calling at the port of Malaga, a total of 470 valid questionnaires were validated. An error of $4.62 \%$ for a confidence level of $95.5 \%$ was obtained $(p=q=0.5)$. As indicated, the fieldwork was conducted during the months of April, May and June 2013.

In our study, sampling is reflected in Table 3:

Table 3 - Technical specifications

\begin{tabular}{|l|l|}
\hline \multicolumn{1}{|c|}{ CHARACTERISTICS } & \multicolumn{1}{c|}{ IDSL CRUISES-79 } \\
\hline Geographical Area & Malaga Port \\
Universe & Cruises Passenger with stop in the Port of Málaga \\
Sample Size & 470 valid questionnaire \\
Sampling Error & $4,62 \%$ \\
Confidence Level & $95,50 \%$ \\
Sampling procedure & Stratified Probabilistic according to Cruises \\
Preliminary questionnaire & Pretest to 10 Cruise Passengers \\
Fieldwork activities & April, may and june 2.013 \\
\hline \multicolumn{2}{|l}{} \\
\hline
\end{tabular}

\subsection{Data analysis}

Data were analyzed with the Statistical Package Software SPSS version 21.0. A cluster analysis applied to the cruise sector has allowed the assessment of whether the data obtained from the sample, can be related in any significant way, which leads us to define certain segments in order to identify different types of cruise passengers.

\subsection{Demographic profile of cruise passengers}

The demographic profile of visitors to the city of Malaga via cruise ship indicated a greater influx of female passengers (53.0\%), compared with male (47.0\%). Slightly less than half of the samples (47.4\%) were between 50 to 70 years old. The main nationalities of interviewees were: English (41.1\%), American (20.2\%), Italian (8.5\%) and German (5.7\%). 
Table 4 - Demographic profile of sample

\begin{tabular}{|c|c|c|c|}
\hline \multicolumn{2}{|c|}{ DEMOGRAPHICS } & \multirow{2}{*}{$\begin{array}{c}\text { FREQUENCY } \\
221\end{array}$} & \multirow{2}{*}{$\frac{(\%)}{47}$} \\
\hline Gender & Male & & \\
\hline 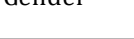 & Female & 249 & 53 \\
\hline \multirow{6}{*}{$\begin{array}{l}\text { Age group } \\
\text { (years) }\end{array}$} & 18 to 30 & 76 & 16,2 \\
\hline & 30 to 40 & 51 & 10,9 \\
\hline & 40 to 50 & 60 & 12,8 \\
\hline & 50 to 60 & 89 & 18,9 \\
\hline & 60 to 70 & 134 & 28,5 \\
\hline & 70 or more & 60 & 12,8 \\
\hline \multirow{4}{*}{ Nationality } & English & 193 & 41,1 \\
\hline & American & 95 & 20,2 \\
\hline & Italian & 40 & 8,5 \\
\hline & German & 27 & 5,7 \\
\hline
\end{tabular}

Source: Authors.

\section{Results}

Cluster analysis was used to identify groups of cruise passengers distinguished by the fact that they express different assessments of the variables analyzed in our theoretical framework.

\section{Cluster description}

A cluster of $K$-media analysis was carried out in order to optimize the homogeneity of the groups of cruise passengers. In our case, the K-media algorithm was equal to 4 , establishing four distinct groups of cruise passengers.

Table 5 shows the number of passengers who have obtained in each cluster.

Table 5 - Size of the clusters

\begin{tabular}{|ccc|}
\hline \multirow{2}{*}{ GROUPS } & $\begin{array}{c}\text { No CRUISES } \\
\text { PASSENGER }\end{array}$ & \% \\
\hline \hline 1 & 106 & $23 \%$ \\
2 & 232 & $49 \%$ \\
3 & 4 & $1 \%$ \\
4 & 128 & $27 \%$ \\
\hline \hline TOTAL & $\mathbf{4 7 0}$ & $\mathbf{1 0 0 \%}$ \\
\hline
\end{tabular}

Source: Authors.

In order to identify the main differences between groups, an ANOVA test for variables IDSL CRUISES-79 was performed. The results are presented in Tables 6, 7 and 8 . It can be seen that the degree of significance for all variables is less than or equal to 0.05 , so that there are significant differences between groups.

Table 6 - ANOVA results Destination Image

\begin{tabular}{|c|c|c|c|c|c|c|c|c|c|c|}
\hline \multirow[b]{2}{*}{ ITEMS DESTINATION IMAGE } & \multicolumn{4}{|c|}{ Clusters } & \multirow{2}{*}{$\begin{array}{c}\text { Groups } \\
\begin{array}{c}\text { Root mean } \\
\text { square }\end{array} \\
\end{array}$} & \multirow[b]{2}{*}{ gl } & \multicolumn{2}{|l|}{ Error } & \multirow[b]{2}{*}{$\mathbf{F}$} & \multirow[b]{2}{*}{ Sig. } \\
\hline & 1 & 2 & 3 & 4 & & & $\begin{array}{c}\text { Root mean } \\
\text { square }\end{array}$ & gl & & \\
\hline \multicolumn{11}{|l|}{ TRAVEL ENVIRONMENT } \\
\hline Pleasant weather & 5 & 6 & 2 & 7 & 102,87 & 3 & 1,52 & 466 & 67,683 & 0,000 \\
\hline Clean and tidy environment & 5 & 6 & 1 & 7 & 125,619 & 3 & 0,839 & 466 & 149,777 & 0,000 \\
\hline Friendly and helpful local people & 5 & 6 & 3 & 7 & 107,505 & 3 & 0,871 & 466 & 123,377 & 0,000 \\
\hline Safe and secure envioronment & 4 & 6 & 1 & 7 & 132,045 & 3 & 0,858 & 466 & 153,881 & 0,000 \\
\hline Picturesque views & 5 & 6 & 2 & 7 & 99,838 & 3 & 0,998 & 466 & 100,051 & 0,000 \\
\hline \multicolumn{11}{|l|}{ ENTERTAINMENT AND EVENTS } \\
\hline Wide arrays of shows/exhibitions & 4 & 4 & 2 & 5 & 45,209 & 3 & 0,91 & 466 & 49,703 & 0,000 \\
\hline Wide variety of entertainment & 4 & 4 & 2 & 5 & 40,021 & 3 & 0,896 & 466 & 44,677 & 0,000 \\
\hline Tempting cultural events & 4 & 4 & 2 & 5 & 47,107 & 3 & 1,06 & 466 & 44,437 & 0,000 \\
\hline \multicolumn{11}{|l|}{ INFRASTRUCTURES } \\
\hline Wide selection of restaurants/cuisine & 5 & 5 & 2 & 6 & 87,959 & 3 & 1,252 & 466 & 70,269 & 0,000 \\
\hline Wide variety of shopping options & 4 & 6 & 2 & 7 & 102,428 & 3 & 1,096 & 466 & 93,448 & 0,000 \\
\hline Wide choice of accommodation & 4 & 4 & 3 & 5 & 43,76 & 3 & 1,074 & 466 & 40,759 & 0,000 \\
\hline \multicolumn{11}{|l|}{ PRICE AND VALUE } \\
\hline Reasonable price for food and accommodation & 4 & 5 & 1 & 6 & 97,215 & 3 & 1,129 & 466 & 86,123 & 0,000 \\
\hline Good value for money & 4 & 5 & 2 & 6 & 96,399 & 3 & 1,235 & 466 & 78,065 & 0,000 \\
\hline Reasonable price for attractions and activities & 4 & 5 & 1 & 6 & 99,07 & 3 & 1,231 & 466 & 80,462 & 0,000 \\
\hline Good bargain shopping & 4 & 5 & 3 & 6 & 112,083 & 3 & 1,376 & 466 & 81,443 & 0,000 \\
\hline \multicolumn{11}{|l|}{ ACCESSIBILITY } \\
\hline Appropriate signposting & 4 & 5 & 1 & 6 & 109,473 & 3 & 1,377 & 466 & 79,491 & 0,000 \\
\hline Easy access to city centre & 5 & 6 & 2 & 7 & 94,681 & 3 & 1,163 & 466 & 81,438 & 0,000 \\
\hline Disabled access & 4 & 5 & 2 & 6 & 62,292 & 3 & 1,305 & 466 & 47,751 & 0,000 \\
\hline Tourism information points & 4 & 6 & 1 & 6 & 104,371 & 3 & 1,224 & 466 & 85,273 & 0,000 \\
\hline
\end{tabular}

Note: Parameters included in each cluster column corresponds to the preference of values of the Likert scale of 7 points. 
Table 7 - ANOVA results Cruise Passengers Satisfaction

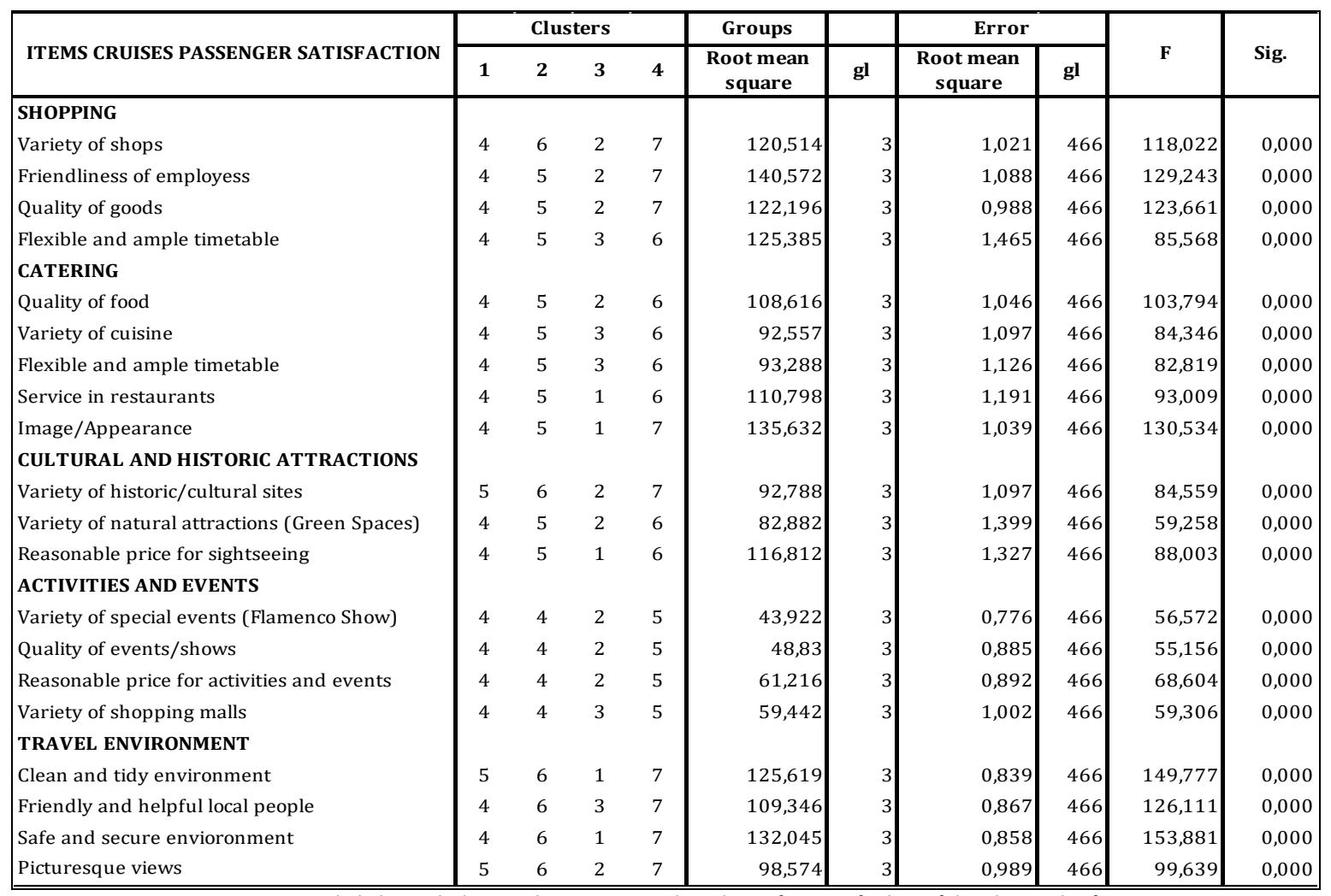

Note: Parameters included in each cluster column corresponds to the preference of values of the Likert scale of 7 points.

Source: Authors.

Table 8 - ANOVA results Destination Loyalty

\begin{tabular}{|c|c|c|c|c|c|c|c|c|c|c|}
\hline \multirow[b]{2}{*}{ ITEMS DESTINATION LOYALTY } & \multicolumn{4}{|c|}{ Clusters } & \multirow{2}{*}{$\begin{array}{c}\text { Groups } \\
\text { Root mean } \\
\text { square }\end{array}$} & \multirow[b]{2}{*}{ gl } & \multicolumn{2}{|l|}{ Error } & \multirow[b]{2}{*}{$\mathbf{F}$} & \multirow[b]{2}{*}{ Sig. } \\
\hline & $\mathbf{1}$ & 2 & 3 & 4 & & & $\begin{array}{c}\text { Root mean } \\
\text { square }\end{array}$ & gl & & \\
\hline Intention to revisit & 4 & 6 & 1 & 7 & 123,045 & 3 & 1,456 & 466 & 84,522 & 0,000 \\
\hline Intention to recommend & 5 & 6 & 1 & 7 & 122,156 & 3 & 0,882 & 466 & 138,555 & 0,000 \\
\hline Overall satisfaction & 5 & 6 & 2 & 7 & 106,657 & 3 & 0,819 & 466 & 130,206 & 0,000 \\
\hline
\end{tabular}

Note: Parameters included in each cluster column corresponds to the preference of values of the Likert scale of 7 points. Source: Authors.

We highlight the cluster group 2, which represents 49 per cent of the total sample. In the figure 1, two rather different conglomerates are observed, on the one hand, group 1 represented by 23 per cent of interviewees, who qualified as
"CLUSTER INDIFFERENCE", segment of cruise passengers mainly indifferent to the issues raised, so their level satisfaction is relative.

Figure 1- Cluster analysis of the variables

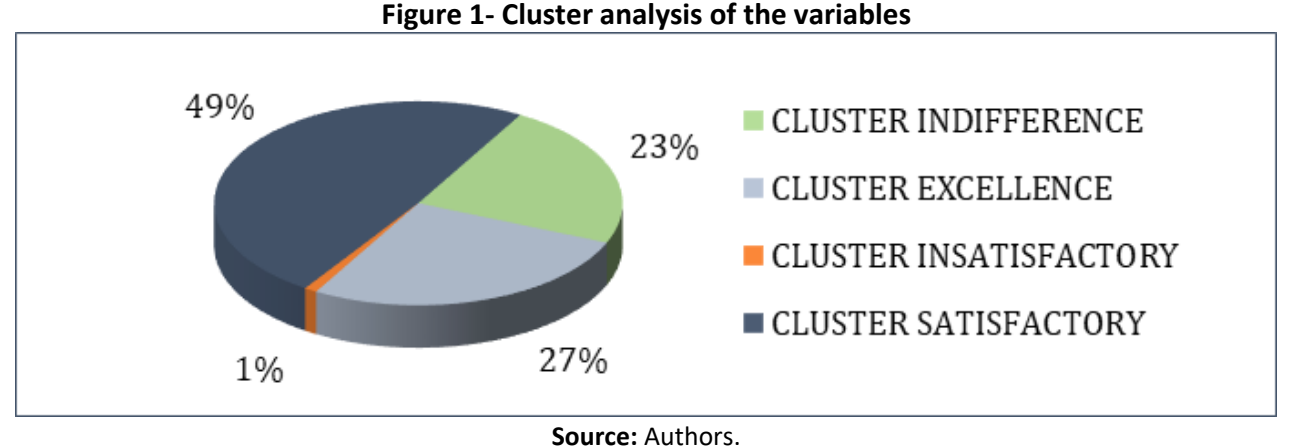

Source: Authors.

On the other hand, the conglomerate group 4, comprising 27 per cent of cruise passengers collected the most satisfied passengers and consequently, the best scores on the questionnaire, a total of 19 out of 42 variables scored with a 7 on the scale Likert. This group has been denominated "CLUSTER EXCELENCE". 
Group 3 cluster consists of passenger manifest "strongly disagree" showing their dissatisfaction in many of the elements of the model variables, specifically in 21 of the 42 items, representing 50 per cent. This cluster has been called "CLUSTER INSATISFACTORY " This segment represents only 1 per cent of the total sample so this information is not relevant.

49 per cent of survey respondents are collected in cluster group 2. It is the most important group; this is the reason why we need to bear in mind their findings, both with regard to their good ratings and those aspects that may be susceptible to improvement. This cluster has been called "CLUSTER SATISFACTORY".

If we focus on the more numerous groups or clusters (group 2 and 4) we can highlight the following:

\section{CLUSTER EXCELLENCE (group 4)}

The group of cruise passengers grouped in the CLUSTER EXCELLENCE expressed greatest satisfaction, scoring with the highest rating all the items listed in Table 9 relating to the three concepts of the theoretical model. Also, it must be explained that other items not annexed in the above table, are also highly valued.

Table 9 - Items cluster excellence

\begin{tabular}{|l|c|}
\hline \multicolumn{1}{|c|}{ ITEMS CLUSTER EXCELLENCE } & $\begin{array}{c}\text { Max. CalifIcation } \\
\text { Likert scale }\end{array}$ \\
\hline TRAVEL ENVIRONMENT & \\
Pleasant weather & \\
Clean and tidy environment & DESTINATION \\
Friendly and helpful local people & IMAGE \\
Safe and secure envioronment & ITEMS \\
Picturesque views & \\
INFRASTRUCTURES & \\
Wide variety of shopping options & \\
ACCESSIBILITY & \\
Easy access to city centre & \\
\hline SHOPPING & \\
Variety of shops & \\
Friendliness of employess & \\
Quality of goods & \\
CATERING & CRUISES PASSENGER \\
Image/Appearance & SATISFACTION \\
CULTURAL AND HISTORIC ATTRACTIONS & ITEMS \\
Variety of historic/cultural sites & \\
TRAVEL ENVIRONMENT & \\
Clean and tidy environment & \\
Friendly and helpful local people & \\
Safe and secure envioronment & \\
Picturesque views & \\
\hline Intention to revisit & \\
Intention to recommend & \\
Overall satisfaction & \\
\hline
\end{tabular}

Source: Authors.

\section{CLUSTER SATISFACTORY (group 2)}

The group of cruise passengers grouped in CLUSTER SATISFACTORY, expressed great satisfaction grading a 6 on the Likert scale. The elements annexed in Table 10 and the remaining elements would be either well appreciated or simply indifferent.
Table 10 - Items cluster satisfactory

\begin{tabular}{|l|c|}
\hline \multicolumn{1}{|c|}{ ITEMS CLUSTER SATISFACTORY } & $\begin{array}{c}\text { 6 Points } \\
\text { Likert scale }\end{array}$ \\
\hline TRAVEL ENVIRONMENT & \\
Pleasant weather & \\
Clean and tidy environment & DESTINATION \\
Friendly and helpful local people & IMAGE \\
Safe and secure envioronment & ITEMS \\
Picturesque views & \\
INFRASTRUCTURES & \\
Wide variety of shopping options & \\
ACCESSIBILITY & \\
Easy access to city centre & \\
Tourism information points & \\
\hline SHOPPING & \\
Variety of shops & CRUISES PASSENGER \\
CULTURAL AND HISTORIC ATTRACTIONS & SATISFACTION \\
Variety of historic/cultural sites & ITEMS \\
TRAVEL ENVIRONMENT & \\
Clean and tidy environment & \\
Friendly and helpful local people & \\
Safe and secure envioronment & \\
Picturesque views & DESTINATION LOYALTY \\
\hline Intention to revisit & ITEMS \\
Intention to recommend & \\
Overall satisfaction & \\
\hline
\end{tabular}

Source: Authors.

In this regard, we consider that the findings of this important segment of passengers are of vital interest to our research, providing us valuable information about the general satisfaction of tourists who are arriving in the city of Malaga via cruise ship. Special emphasis has also been placed on those variables with very good valuations; we will have to take them into account to empower them and promote the marketing campaigns of the city.

\section{Conclusions, discussion and recommendations}

After the cluster analysis the following conclusions, taking into account the hypothesis involved at the time have been reached.

First, in relation to hypothesis 1 :

- $\mathrm{H}_{1}$ : Are there different segments of cruise passengers, regarding the perception of destination image of Malaga?

We conclude that there are different segments of cruise passengers, regarding the perception of the image of the destination Malaga. It is noted that of all the factors that describe the destination image, those related to Environment and Accessibility have been the highest rated.

In particular, we highlight the interest shown in the great views of the city of Malaga and its picturesque icons and, regarding the Environment factor, cleanliness and safety of the Historical Centre.

The new port infrastructures have provided the tourist sector with a greater ease of access to the city from the cruise terminal, reflected in the satisfactory appreciations of cruise passengers, improving the destination image. Also, it has been stated that there is a large segment of passengers that also feel satisfied with safety, cleanliness and hospitality. 
In connection with the Price and value factor, cruise passengers have expressed an opinion not so satisfactory in variables like good value for money in relation to the services and activities offered by the city, whether commercial, recreational or even historical-cultural.

Similarly, the reasonable price variable for tourism activities has been one of the worst rated by cruise passengers, along with great shopping opportunities.

In relation to passenger satisfaction, we can test hypothesis 2 :

- $\mathrm{H}_{2}$ : Are there different segments of cruise passengers regarding the satisfaction variable, in their perception of the city of Malaga?

It is concluded that we do perceive the existence of different categories of cruise passengers regarding their perceptions of the city of Malaga.

The most valued factor by cruise passengers has been precisely that related to the Historical-cultural importance, which the city of Malaga has to do this day.

Of the three variables that describe this factor the indicator has certainly been "Malaga has a great cultural offer", which has been highlighted over others. It has also been reflected in this study that cruise passengers are very satisfied with the cultural offer of the capital, the visits to monuments and museums. So we can state that the historical and cultural attractions are a tourist attraction for the cruise passengers who are visiting the city of Malaga.

Regarding hypothesis 3:

- $\mathrm{H}_{3}$ : Are there different segments of cruise passengers, regarding the destination loyalty variable in the context of Malaga?

We conclude that we do have different segments of cruise passengers with respect to destination loyalty. It is appreciated that a very high percentage of cruise passengers have expressed a high destination loyalty and the recommendation of this city to their environment.

The analysis of socio-demographic characteristics reveals the existence of differences concerning gender. In almost all factor variables of the levels of appreciation of the female sex prevailed over the male.

In addition, the more demanding age range has been between 50 to 60 years of age and regarding the study of nationalities it should be clear the figure of the American passenger, who has expressed better valuations than other survey respondents, according to the ratings in IDSL CRUISES-79.

The conclusions obtained in the research lead us to bring a set of recommendations which; we understand are significant to improving cruise tourism in the city of Malaga.

The data obtained from this research have so many practical implications. On one hand we consider that both public and private institutions could use this information and implement policies in order to improve the services which are offered to cruise passengers.

We understand that public institutions and traders need to reflect on the connection between the quality and price of services and activities, because if this assessment is not excellent, as we argued, it may affect the destination image of the city and in addition, may condition the intention of repeating the visit.

The strengthening of Malaga as a cultural top-rated destination is consolidated with the opening of two new museums, the Centre Pompidou Malaga, which opened its doors in the spring of 2015 and the Collection of Saint Petersburg the Russian Museum in the capital, thus expanding cultural roots.

We think that the facilities offered by 'Muelle Uno', could become a perfect combination of culture, commerce and gastronomy, linking the visit to the new Pompidou, located next to the food court and shops, especially for cruise passengers arriving at dock 2. Passengers with a high level of income, with options to frequent the most exclusive shops and restaurants of the zone.

In terms of scarcity, we think that the information points need to professionalize their services to a greater extent because in some of the interviews with both cruise passengers and staff on board, there were indicators to the importance of these points when visiting Malaga for the first time.

In line with this idea we emphasize that an association of tour guides has recently formed, who stand around "Cultural Malaga AGP". They aim to expose the cultural keys of Malaga in search of a higher quality service.

The emblematic symbol of 'Malaga marinera' (Maritime Malaga), which is 'La Farola' (a lighthouse), is going to waste, above all if we take into account its situation at the entrance of 'Muelle Uno', near the cruise terminals, it could be remodeled and used for a different purpose. On the one hand, it could be used for attending to tourist cruises, with staff ready to exercise as genuine cicerones of the city. It would benefit the quality of the information service provided to cruise passengers.

On the other, it could also serve as a meeting point where the agents involved in the business could contact the tourists, explaining all itineraries and routes that can be followed on the visit to the city and in any event, encourage business lines, which aim to strengthen links between shipping companies and cruise tourism in Malaga.

Raising the image of Malaga and the increasing variety of gastronomical option in the old town have been perceived satisfactorily by the collective of passengers, due to this, we believe that cruise passengers are satisfied with the options offered and in turn, this circumstance improves the image of the city. 
Although the factors and selected variables for measuring the image of the destination and cruise passenger satisfaction were chosen following a rigorous review of the literature, the study has some limitations.

On the one hand, we recognize that there are other attributes that could have been studied and are not included in the model; among them we can mention emotions, authenticity, tourist expectations prior to the visit or the quest for novelty. All of them are factors that many authors have collected in their models to measure variables; we could consider them potential factors. As suggested, a modification of the theoretical model proposed for future research.

In addition, the study is geographically limited to a region of southern Spain; consequently, this limits the possibility of a broader view of the results and also, the possibility of having a larger sample size. In this sense, the research could also be repeated elsewhere to verify if there are differences in other destinations.

Finally, the longitudinal approach gives us results referring to a certain point of time, one where the data was obtained, so that in a later context, the findings and/or results of the cluster analysis may be modified.

Lastly, through the cluster analysis we were able to verify the different profiles of cruise passengers arriving in Malaga and identify what the strengths are and how they can be improved.

The data obtained are mostly positive, 76 per cent of the sample (360 passengers out of a total of 470 passengers); grouped in the CLUSTER EXCELLENCE and CLUSTER SATISFACTORY, expressing great satisfaction with the issues raised in the IDSL CRUISES-79.

In short, we can also say that this research has provided a better understanding of the qualities and excellences of the city of Malaga through the eyes of the cruise passenger, who was shown to be faithful to destination. Their future recommendations provide us with a return of passengers which is of interest for the economy of the city.

\section{References}

Alqurneh, M., Md Isa, F. \& Rahim, A. (2010). Tourism destination image, satisfaction and loyalty: A study of the Dead Sea in Jordanian curative tourism. Paper presented at The Third International Conference on International Studies (ICIS 2010), Hotel Istana Kuala Lumpur. College of Law. Government and International Studies, University Utara Malaysia. Sintok, 1-10.

Baloglu, S. \& McCleary, K.W. (1999). A model of destination image formation. Annals of Tourism Research, 4(26), 868-897.

Barich, H. \& Kotler, P. (1991). A framework for marketing image management. Sloan Management Review, 32, 94-104.

Beerli, A. \& Martin, J. D. (2004). Factors influencing destination image. Annals of Tourism Research, 3(31), 657-681.

Carvajal-Trujillo, E \& Sanz, S. (2015). The moderating effects of personal and situational characteristics on the image, satisfaction and future behavioral intention with ports of calls. In: 2nd International Symposium on Partial Least Squares Path Modeling - The Conference for PLS Users., 16 June 2015 - 19 June 2015, Seville, Spain
Cater, B. \& Zabkar, V. (2009). Antecedents and consequences of commitment in marketing research services: The client's perspective. Industrial Marketing Management, 38(7), 785-797.

Coban, S. (2012). The effects of the image of destination on tourist satisfaction and loyalty: the case of Cappadocia, European Journal of Social Science, 2(29), 222-232.

Devesa Fernández, M. \& Palacios Picos, A. (2005). Predicciones en el nivel de satisfacción percibida por los turistas a partir de variables motivacionales y de valoración de la visita. Información Comercial española: Tribuna de Economía, 821, 241-255.

Echtner, C.M. \& Ritchie, J.R. (2003). The meaning and measurement of destination image. The Journal of Tourism Studies, 14(1), 37-48.

Ejarque, J. (2005). Destinos turísticos de éxito: Diseño, creación, gestión y marketing. Madrid: Piramide.

Eusebio, C. \& Vieira, A.L. (2011). Destination attributes' evaluation, satisfaction and behavioural intentions: a structural modelling approach. International Journal of Tourism Research, 15(1), 66-80.

Ferreira Lopes, S.D. (2011). Destination image: origins, developments and implications. Revista de Turismo y Patrimonio Cultural, 2(9), 305-315.

Fyall, A., Callod, C. \& Edwards, B. (2003). Relationship marketing. The challenge for destinations. Annals of Tourism Research, 30(3), 644-659.

Geng-Quin Chi, C. \& Qu, H. (2008). Examining the structural relationships of destination image, tourist satisfaction and destination loyalty: an integrated approach. Tourism Management, 29(4), 624-636.

Geng-Quin Chi, C. \& Qu, H. (2009). Examining the relationship between tourist's attribute satisfaction and overall satisfaction. Journal of Hospitality Marketing \& Management, 18, 4-25.

Geng-Quin Chi, C., Xiaoxia, S. \& Honggang, X. (2013). Developing destination loyalty: the case of Hainan Island. Annals of Tourism Research, 43, 547-577.

Giese, J.L. \& Cote, J. A. (2000). Defining consumer satisfaction. Academy of Marketing Science Review, 1, 1-24.

Hunt, J.D. (1975). Image as a factor in tourism development, Journal of Travel Research, 13, 1-7.

Jamaludin, M., Johari, S., Aziz, A., Kayat, K. \& Yusof, A. R. M. (2012). Examining Structural Relationship between Destination Image, Tourist Satisfaction and Destination Loyalty. International Journal of Independent Research and Studies, 1(3), 89-96.

Kim, H. \& Richardson, S. L. (2003). Motion picture impacts on destination images. Annals of Tourism Research, 30(1), 216-237.

Kozak, M. \& Rimmington, M. (2000). Tourist satisfaction with Mallorca, Spain, as an off-season holiday destination. Journal of Travel Research, 3(38), 260-269.

Lawson, F. \& Baud-Bovy, M. (1977). Tourist and recreational development. London: Architectural Press.

Lee, T.H. (2009). A structural model for examining how destination image and interpretation services affect future visitation behavior: a case study of Taiwan's Taomi eco-village. Journal of Sustainable Tourism, 6 (17), 727-745.

Medlik, S. \& Middleton, V.T.C. (1973). The tourist product and its marketing implications. International Tourism Quarterly, 3(1), 28-35.

Murphy, P., Pritchard, M.P. \& Smith, B. (2000). The destination product and its impact on traveler perceptions. Tourism Management, 21(1), 43-52.

Nunnally, J. C., \& Bernstein, I. H. (1994). Psychometric theory (3rd ed.). New York: McGraw-Hill.

Oliver, Richard L. (1997). Satisfaction: a behavioral perspective on the consumer. New York: Irwin/McGraw-Hill.

Prayag, G. (2008). Image, satisfaction and loyalty - the case of Cape Town. Anatolia: An International Journal of Tourism and Hospitality Research, 19(2), 205-224.

Prayag, G. \& Ryan, C. (2012). Antecedents of tourists' loyalty to Mauritius: the role and influence of destination image, place 
attachment, personal involvement, and satisfaction. Journal of Travel Research, 51(3), 342-356.

Rajesh, R. (2013). Impact of tourist perceptions, destination image and tourist satisfaction on destination loyalty: a conceptual model. PASOS, 11(3), 67-78.

Sanz, S \& Carvajal-Trujillo, E. (2014). The case study of Valencia. Ocean \& Coastal Management, 102,(A), 307-16.

Shirazi, S. F. M. \& Som, A. P. M. (2011). Destination management and relationship marketing: two major factors to achieve competitive advantage. Journal of Relationship Marketing, 10(2), 76-87.

Sonmez, S. \& Sriakaya, E. (2002). A distorted destination image? The case of Turkey. Journal of Travel Research, 41, 185-196.

Stepchenkova, S. \& Mills, J.E. (2010). Destination image: a meta-analysis of 2000-2007 research. Journal of Hospitality Marketing \& Management, 19(6), 575-609.

Tasci, A., Gartner, W. \& Cavusgil, S. (2007). Measurement of destination brand bias using a quasi-experimental design. Tourism Management, 28, 1529-1540.

Valls, J.F. (2004). Gestión de destinos turísticos sostenibles. Ediciones Gestión 2000.

Xie, H. J., Kerstetter, D. L., \& Mattila, A. S. (2012). The attributes of a cruise ship that influence the decision making of cruisers and potential cruisers. International Journal of Hospitality Management, 31(1), 152-159.

Yoon, Y. \& Uysal, M. (2005). An examination of the effects of motivation and satisfaction on destination loyalty: a structural model. Journal of Tourism Management, 26(1), 45-56.

Zeithaml, V.A., Berry, L.L., \& Parasuraman, A. (1996). The behavioural consequences of service quality. Journal of Marketing, 60(2), 31-46.

Received: 13 May 2016

Revisions required: 27 January 2017

Accepted: 14 April 2017 